IN order to elucidate further the possible role of specific cytokines in the pathogenesis of atopic dermatitis (AD) the in vitro production of interleukin 4 (IL-4) and interferon-gamma (IFN- $\gamma$ ) in patients with severe atopic dermatitis $(n=4)$ was compared with that in a group of non-atopic healthy controls. Overall IL-4 production by PHA- and PWM-driven PBMNCs was increased in controls during the first $48 \mathrm{~h}$ in culture. Addition of interleukin 2 (IL-2) into parallel cultures generated an insignificant $(p>0.05)$ increase in IL-4 production in AD patients compared with that from controls. IFN- $\gamma$ production by PWM-stimulated PBMNCs was markedly decreased in AD patients compared with controls $(p<0.01)$. Addition of IL-2 $(250 \mathrm{U} / \mathrm{ml})$ to parallel cultures failed to restore IFN- $\gamma$ production in AD patients. Finally, no IL-4 or IFN- $\gamma$ activity could be detected in any of the sera. In conclusion, the data suggest a possible dysregulation of cytokine production in at least a subgroup of $\mathrm{AD}$ patients, with an impaired capacity to secrete IFN- $\gamma$, but a partially intact IL-4 generating capacity.

Key words: Atopic dermatitis, Children, In vitro interleukin 4 and interferon- $\gamma$ production

\section{In vitro interleukin 4 and interferon-gamma production by mononuclear cells from atopic dermatitis patients}

\author{
Serge Well and Friedhelm Diel ${ }^{\mathrm{CA}}$
}

Department of Nutrition, Fachhochschule Fulda, FB HE, Marquardstr. 35, 36039 Fulda, Germany

${ }^{\mathrm{CA}}$ Corresponding Author

\section{Introduction}

Although atopic dermatitis (AD) is a chronic, pruritic, inflammatory skin disorder first described as a disease entity in the early decades of this century, its etiopathogenesis has not yet been fully elucidated. In addition to genetic disposition, AD is influenced by many environmental factors. Numerous humoral and cellular immunological abnormalities have been reported in $\mathrm{AD},{ }^{1}$ including high $\operatorname{IgE}$ levels, increased numbers of $\operatorname{IgE}-\mathrm{Fc}$ receptor (FceR) bearing lymphocytes, and cellular dysfunctions in T-cells. In the murine system ${ }^{2,3}$ as well as in humans ${ }^{4} \mathrm{~T}$-helper cells can be divided into two subsets $\left(\mathrm{TH}_{1}\right.$ and $\left.\mathrm{TH}_{2}\right)$ on the basis of the cytokines they produce: $\mathrm{TH}_{1}$ cells secrete interleukin 2 (IL-2) and interferon-gamma (IFN- $\gamma$ ) and $\mathrm{TH}_{2}$ cells secrete interleukin 4 (IL-4) and interleukin 5 (IL-5). Evidence has accumulated that the human $\mathrm{IgE}$ response is mainly regulated by the relative production of the reciprocally active cytokines IL-4 $\left(\mathrm{TH}_{2}\right.$ system) and IFN- $\gamma\left(\mathrm{TH}_{1}\right.$ system).$^{5-8}$ Both recombinant and natural IL-4 induce IgE synthesis by peripheral blood mononuclear cells (PBMNCs) from atopic and healthy donors. ${ }^{9-11}$ IFN- $\gamma$ downregulates this IL-4 induction of $\operatorname{IgE}$ synthesis in vitro. ${ }^{5,12-14}$ It has been suggested that in atopic individuals allergens may 'select' T-helper cells with peculiar profiles of cytokine production (high IL-4 and low IFN- $\gamma$ ), thus contributing to the pathogenesis of IgE-mediated disorders. ${ }^{6}$ Only a few studies have investigated the simultaneous production of IL-4 and IFN- $\gamma$ in vitro using activated PBMNCs cultures from atopic donors. ${ }^{15-17}$ The results have been in part controversial with respect to IL-4 ${ }^{15-17,18}$ and IFN- $\gamma^{16,17,19,20}$ production. These data prompted the authors to examine whether IL-4 and IFN- $\gamma$ activity could be detected in the supernatants (SN) of plant lectin-stimulated (PHA and PWM) PBMNC cultures from $\mathrm{AD}$ patients with moderate to severe disease activity using commercially available ELISAs. ${ }^{21}$ In order to investigate the in vitro effect of IL-2, a T-cell growth factor described as being required for IL-4 production ${ }^{22,23}$ as well as capable of mediating IFN- $\gamma$ generation, ${ }^{24}$ exogeneous rhIL-2 was added to parallel PBMNC cultures. We finally investigated whether PBMNCs from atopic patients with severe disease scores produced altered levels of IL-4 and IFN- $\gamma$ compared with those from controls.

\section{Materials and Methods}

Subjects: Four atopic patients (all male; mean age 12 years, range 9-14 years) were selected on the basis of a positive history for allergies. They all suffered from atopic dermatitis as defined by the criteria of Hanifin and Rajka, ${ }^{25}$ allergic rhinitis and mild or severe allergic asthma, and had elevated serum total IgE levels (mean $4714 \mathrm{IU} / \mathrm{ml}$, range $222-10920 \mathrm{IU} / \mathrm{ml}$ ) using the Phadezym 
IgE Prist test (Pharmacia Biosystems, Freiburg, Germany). Three of four atopic patients had acute exacerbation of AD, with severe episodes of itching, paralleled by nocturnal asthmatic attacks, requiring various therapeutic regimens including topical emollients, ambulant photo-balneotherapy and/or elimination diets. The control group consisted of four healthy individuals (all male; mean age 20 years, range 8-29 years) with a negative history of atopy; their total serum $\operatorname{IgE}$ levels were $<50 \mathrm{IU} / \mathrm{ml}$; no elevated specific $\mathrm{IgE}$ levels to the most common allergens were detected in the sera using the Phadezym RAST test (Pharmacia).

Reagents: RPMI 1640 medium, supplemented with $300 \mathrm{mg} / \mathrm{ml}$ L-glutamine, $100 \mathrm{U} / \mathrm{ml}$ penicillin, 100 $\mathrm{mg} / \mathrm{ml}$ streptomycin, $10 \%$ heat-inactivated $(30 \mathrm{~min}$, $56^{\circ} \mathrm{C}$ ) foetal bovine serum, and $25 \mathrm{mM}$ HEPES buffer, phytohaemagglutinin (PHA), pokeweed mitogen (PWM), and recombinant human interleukin 2 (rhIL-2) were all obtained from Sigma Chemie, Deisenhofen, Germany. Ficoll-Hypaque ${ }^{\circledR}$ was obtained from Pharmacia, Freiburg, Germany.

Cells and cultures: PBMNCs were isolated from heparinized peripheral blood by centrifugation on a density gradient of Ficoll-Hypaque, ${ }^{26}$ extensively washed and resuspended at $10^{6}$ cells $/ \mathrm{ml}$ of complete medium. $200 \mu \mathrm{l}$ of cell suspension/well were cultured with or without PHA or PWM (at final concentrations of $5.0 \mu \mathrm{g} / \mathrm{ml}$ ), either in the presence or absence of IL-2 $(250 \mathrm{U} / \mathrm{ml})$ in 96-well, flat-bottomed, polystyrene microtitre plates (Corning ${ }^{\circledR}$, Sigma Chemie) at $37^{\circ} \mathrm{C}, 95 \%$ humidity, and $10 \% \mathrm{CO}_{2}$ in air for $48 \mathrm{~h}$. At $24 \mathrm{~h}$ and $48 \mathrm{~h}$ after initiation the culture supernatants (SN) were harvested by centrifuging the samples at $350 \times \mathbf{g}$ for $10 \mathrm{~min}$ at room temperature. The cell pellets were resuspended in fresh complete RPMI 1640 medium. The SNs were stored in aliquots at $-70^{\circ} \mathrm{C}$ until tested.

Cytokine assays: IL-4 was determined in the SNs of the PBMNC cultures using a commercially available ELISA (Quantikine ${ }^{\circledR}$, Biermann Diagnostics, Bad Nauheim, Germany). The same technique was used for measuring IL-4 in the donors' sera, which were frozen at $-20^{\circ} \mathrm{C} 1 \mathrm{~h}$ after collection and centrifugation. The calculated lower limit of detection of this ELISA is $2-3 \mathrm{pg} / \mathrm{ml}$ with a confidence of $96 \%$. The $\mathrm{SNs}$ and sera were assayed for IFN- $\gamma$ with a commercially available ELISA for human IFN- $\gamma$ (HB'T, Biermann Diagnostics). According to the manufacturer 1 unit of natural human IFN- $\gamma$ corresponds to between 50 and $100 \mathrm{pg}$, depending on the batch. Each sample was measured in duplicate unless stated otherwise.

$\left[{ }^{3} \mathrm{H}\right]$-thymidine incorporation assay: Proliferation of the
PBMNCs in culture was assessed by a standard $\left[{ }^{3} \mathrm{H}\right]$-thymidine incorporation assay.

Statistical evaluations: Differences in levels of IL-4 and IFN- $\gamma$ between AD patients and controls were analysed by Student's $t$-test. Correlations between cytokine production and $\operatorname{IgE}$ serum concentration were calculated by simple linear regression analysis and tested for statistical significance. Owing to the small samples sizes, descriptive rather than confirmatory statistics were intended.

\section{Results}

IL-4 and IFN- $\gamma$ in human serum: No IL-4 or IFN- $\gamma$ activity could be detected in the non-concentrated sera from $\mathrm{AD}$ patients or healthy controls with the above described ELISA techniques (IL$4<3 \mathrm{pg} / \mathrm{ml}$ resp. IFN- $\gamma<1 \mathrm{pg} / \mathrm{ml}$ ).

Time course of cytokine production in PBMNC cultures: IL-4 and IFN- $\gamma$ were not spontaneously secreted by PBMNCs from either group. The time courses (over $48 \mathrm{~h}$ ) of cytokine production by PBMNCs from AD patients after addition of PHA $(5.0 \mu \mathrm{g} / \mathrm{ml})$ or PWM $(5.0 \mu \mathrm{g} / \mathrm{ml})$ are shown in Fig. 1.

\section{IL-4 and IFN- $\gamma$ production in PBMNC cultures (at $24 \mathrm{~b})$ :}

Effects of PWM stimulation: PWM $(5.0 \mu \mathrm{g} / \mathrm{ml})$ induced IL-4 production (at $24 \mathrm{~h}$ ) by PBMNCs from AD patients was not increased significantly compared with controls. PWM-induced IFN- $\gamma$ generation (at $24 \mathrm{~h}$ ) in AD patients (mean $5.5 \pm 5.4 \mathrm{U} / \mathrm{ml})$ was decreased significantly $(p<$ 0.01 ) compared with controls (mean $42.5 \pm$ $12.3 \mathrm{U} / \mathrm{ml}$ ) (Fig. 2).

Effects of $\mathrm{PHA}$ stimulation. PHA $(5.0 \mu \mathrm{g} / \mathrm{ml})$ induced IL-4 production as well as IFN- $\gamma$ generation (at $24 \mathrm{~h}$ ) by PBMNCs from AD patients

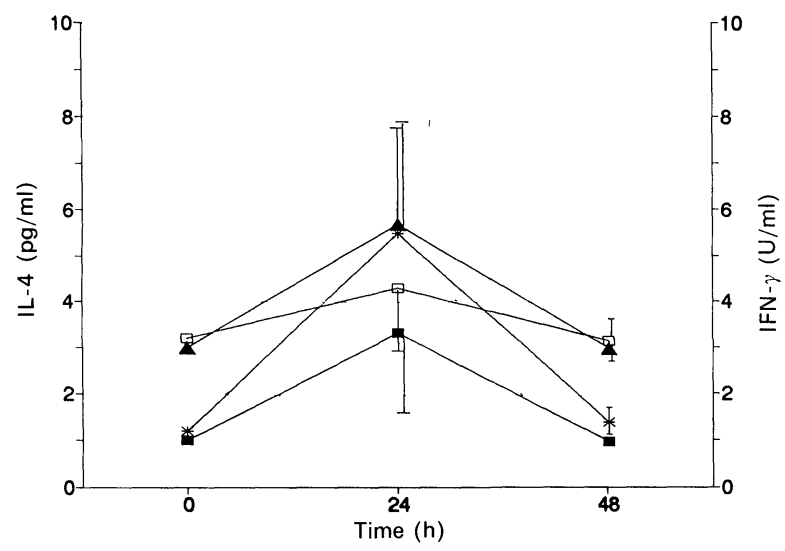

FIG 1 Kinetics of in vitro IL-4 and IFN- $\gamma$ production by PBMNCs from AD patients $(n=4)$ with increased serum lgE levels; $10^{6} \mathrm{PBMNCs} / \mathrm{ml}$ of complete RPMI 1640 medium were stimulated with $5 \mu \mathrm{g} / \mathrm{ml}$ of PHA or $5 \mu \mathrm{g} / \mathrm{ml}$ of PWM. After 24 and $48 \mathrm{~h}$, SNs were harvested and assayed for $\mathrm{IL}-4$ (PHA $=$ plain triangles; $\mathrm{PWM}=$ open squares) and IFN- $\gamma(\mathrm{PHA}=$ plain squares; $P W M=$ stars) activity. Each sample was measured in duplicate. Values are expressed as means \pm S.E.M. 


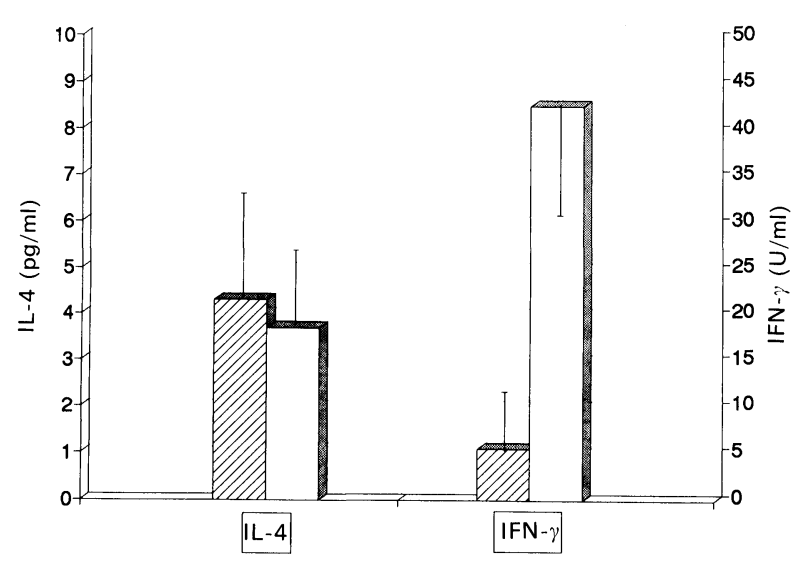

FIG. 2. Cytokine production in vitro by PWM-stimulated PBMNCs. PWM-induced IL-4 generation by PBMNCs from AD patients (hatched bars) (at $24 \mathrm{~h}$ ) was not significantly increased $(p \leq 0.05)$ compared with that from controls (open bars). PWM-induced IFN- $\gamma$ generation (at $24 \mathrm{~h}$ ) in $A D$ patients (mean $5.5 \pm 5.4 \mathrm{U} / \mathrm{ml}$ ) was significantly decreased $(p<0.01)$ compared with that in controls (mean $42.5 \pm 12.3 \mathrm{U} / \mathrm{ml}$ ) Values are expressed as means \pm S.E.M.

did not differ significantly from controls (data not shown).

Effects of IL-2 supplementation. In order to investigate the IL-2 requirement for IL-4 generation, rhIL-2 $(250 \mathrm{U} / \mathrm{ml})$ was added with PWM or PHA. IL-2 supplementation did not increase IL-4 production significantly in AD patients and controls. We further investigated whether IL-2 can restore the impaired IFN- $\gamma$ production in AD patients. No significant difference was observed between IFN- $\gamma$ secretion (at $24 \mathrm{~h}$ ) upon PWM plus IL-2 stimulation compared with PWM stimulation alone (Fig. 3) or PHA plus IL-2 stimulation compared with PHA stimulation alone.

Correlation between cytokine production and IgE serum concentration: A significant positive correlation existed between in vitro PHA- $(r=0.85, p<0.05)$ and PWM- $(r=0.98, \quad p<0.00005)$ induced IFN- $\gamma$

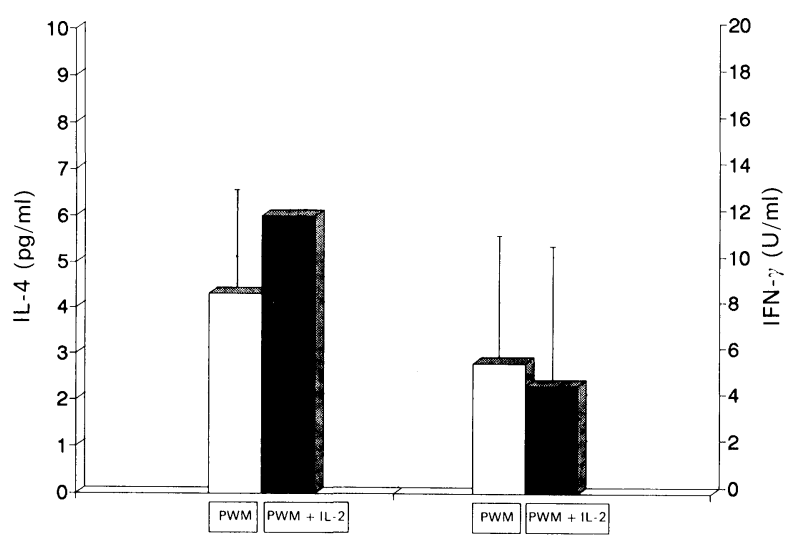

FIG. 3. Effects of IL-2 addition on PWM-induced cytokine production Addition of IL-2 $(250 \mathrm{U} / \mathrm{ml})$ to PWM-stimulated PBMNCs (black bars) of $A D$ patients did not significantly increase IL-4 production (at $24 \mathrm{~h}$ ) compared with that of cultures grown with PWM alone (open bars). No significant difference was observed between IFN- $\gamma$ secretion (at $24 \mathrm{~h}$ ) upon PWM plus IL-2 stimulation compared with PWM stimulation alone. Values are expressed as means \pm S.E.M. secretion and total IgE serum concentration in AD patients; no significant correlation was observed between PHA or PWM-induced IL-4 secretion and total IgE serum concentration (data not shown).

\section{Discussion}

In this study the in vitro production of IL-4 and IFN- $\gamma$ by PBMNCs from AD patients was compared with that of healthy controls. In agreement with other published data, neither IL-4 ${ }^{16}$ nor IFN- $\gamma^{19}$ could be detected in any of the sera. This is in contrast to data published by Matsumoto et al., ${ }^{27}$ where serum concentrations of IL-4 could be measured in children with allergic diseases as well as in non-allergic controls. Differences in the IL-4 assays used might partly account for these discrepancies.

More importantly, in vitro PWM-induced IFN- $\gamma$ production by PBMNCs from AD patients was significantly lower compared with controls (Fig. 2). An accepted view is that the elevated serum $\operatorname{IgE}$ levels in atopic individuals are a consequence of imbalances between IL-4-producing and IFN- $\gamma$ producing helper T-cells. ${ }^{28}$ Parronchi et al. ${ }^{29}$ suggested that the high amounts of IL-4 without simultaneous IFN- $\gamma$ production by allergen-specific TH cells induces the formation of $\operatorname{IgE}$ antibodies. The defective IFN- $\gamma$ production in $\mathrm{AD}$ patients observed here might not be able to successfully down-regulate IL-4-induced $\operatorname{IgE}$ synthesis in vivo in these individuals, whereas high IFN- $\gamma$ levels in healthy controls might successfully antagonize the IL-4-induced $\operatorname{IgE}$ synthesis. However, as unseparated PBMNCs were used as the cell source in this study the potential contribution of monocytes to the measured IFN- $\gamma$ production is difficult to assess. Del Prete et al. ${ }^{30}$ reported defective IFN- $\gamma$ production in the hyper IgE syndrome. A severe deficiency in IFN- $\gamma$ production by PBMNCs from AD patients was observed after PHA stimulation $^{31,32}$ as well as concanavalin stimulation. ${ }^{33}$ In this study defective IFN- $\gamma$ production in $\mathrm{AD}$ patients has been shown by using PWM, another lectin that does not bypass the transmembrane signalling when stimulating PBMNCs.

As IL-2 can mediate mitogen-induced IFN- $\gamma$ production, ${ }^{24}$ the authors investigated whether stimulation with mitogen plus IL-2 could restore decreased IFN- $\gamma$ production by PBMNCs in vitro. Supplementing PBMNCs from AD patients with up to $250 \mathrm{U} / \mathrm{ml}$ of IL-2 failed to restore PWM- or PHA-induced IFN- $\gamma$ production. At this final concentration even IL-2 had a depressive effect on IFN- $\gamma$ production. Taken together, these data suggest that the reported defective IL-2 production $^{34}$ in $\mathrm{AD}$ patients is possibly not responsible for the decreased IFN- $\gamma$ production by PBMNCs. 
The observed positive correlation in AD patients between in vitro IFN- $\gamma$ production and total serum $\mathrm{IgE}$ is in apparent conflict with the view that IFN- $\gamma$ down-regulates $\operatorname{IgE}$ production and in contrast with another report. ${ }^{31}$

The data presented here do not demonstrate a significant difference between PHA/PWM-induced IL-4 production in AD patients and controls (Fig. 2). Supplementation with IL-2 $(250 \mathrm{U} / \mathrm{ml})$ failed to induce a significant increase in IL-4 generation from PHA/PWM-stimulated PBMNCs from AD patients. Seder et al. ${ }^{35}$ have shown that the frequency of IL-4 producing cells is very low among circulating antigen-primed T-cells; furthermore several groups recently reported evidence for the accumulation and expansion of T-lymphocytes producing high amounts of IL-4 in lesional skin, whereas T-lymphocytes from peripheral blood were poor IL-4 producers. ${ }^{36,37}$ Further investigations should compare the cytokine profiles from lesional skin cells and the data obtained here from peripheral blood cells in the same AD individuals. However it is remarkable that, despite the now accepted view that IFN- $\gamma$ and IL- 4 predominantly act at a local level, a highly significant decreased in vitro IFN- $\gamma$ production can be observed among peripheral blood MNCs.

In contrast to IL-4, no correlation between IFN- $\gamma$ production and cell proliferation was observed. However, Patarca et al. ${ }^{38}$ demonstrated that activation of $\mathrm{TH}_{1}$ cells does not necessarily result in IFN- $\gamma$ production.

In conclusion, although the number of investigated individuals is small, we could demonstrate a defective in vitro IFN- $\gamma$ production in PBMNCs from patients with mild to severe forms of $A D$ and moderate to high total serum IgE concentrations, whereas no significant difference in IL-4 secretion was observed in these patients when compared with controls.

\section{References}

1. Leung DYM, Geha RS. Immunoregulatory abnormalities in atopic dermatitis. Clin Rej Allergy 1986; 4: 67-86.

2. Mosmann TR, Coffman RL. Two types of mouse helper T cell clones. Immunol Today 1987; 8: 223-3\%.

3. Coffmann RL, Seymour BWP, Lebman DA et al. The role of helper $\mathrm{T}$ cell products in mouse B cell differentiation and isotype regulation. Immunol Re 1988; 102: $5-28$

4. Wierenga EA, Snoek M, De Groot $C$ et al. Evidence for compartmentalization of functional subsets of $\mathrm{CD}^{+}{ }^{+} \mathrm{T}$ lymphocytes in atopic patients. Immunol 1990; 144: 4651-4656.

5. Pène J, Rousset F, Brière F et al. IgE production by normal human lymphocytes is induced by interleukin 4 and suppressed by interferons $\gamma$ and $\alpha$ and prostaglandin $\mathrm{E}_{2}$. Proc Natl Acad Sci USA 1988; 85: 6880-6884.

6. Romagnani S. Regulation and deregulation of human IgE synthesis. Immunol Today 1990; 11: 316-321.

7. de Vries JE, Gauchat J-F, Aversa GG, Punnonen J, Gascan H, Yssel H. Regulation of IgE synthesis by cytokines. Curr Opin Immunol 1991; 3 851-858

8. Chrétien I, Pène J, Brière F, de Waal Malefijt R, Rousset F, de Vries JE Regulation of human $\operatorname{IgE}$ synthesis. I. Human $\operatorname{IgE}$ synthesis in vitro is determined by the reciprocal antagonistic effects of interleukin 4 and interferon- $\gamma$. Eur J Immunol 1990; 20: 243-251.
9. Pène J, Rousset F, Brière $\mathrm{F}$ et al. IgE production by normal B cells induced by alloreactive $\mathrm{T}$ cell clones is mediated by IL-4 and suppressed by IFN- $\gamma$. J Immunol 1988; 141: 1218-1224.

10. Del Prete G, Maggi E, Parronchi P et al. IL-4 is an essential factor for the $\mathrm{IgE}$ synthesis induced in vitro by human $\mathrm{T}$ cell clones and their supernatants. I Immunol 1988; 140: 4193-4198.

11. Claasen JL, Levine AD, Buckley RH. Recombinant human IL-4 induces IgE and $\mathrm{IgG}$ synthesis by normal and atopic donor mononuclear cells. J Immuno 1990; 144: 2123-2130.

12. Pène $\mathrm{J}$, Rousset $\mathrm{F}$, Brière $\mathrm{F}$ et al. IgE production by normal human $\mathrm{B}$ cells induced by alloreactive $\mathrm{T}$ cell clones is mediated by $\mathrm{IL}-4$ and suppressed by IFN- $\gamma$. J Immunol 1988; 141: 1218-1224.

13. Romagnani S, Del Prete G, Maggi E et al. Role of interleukins in induction and regulation of human IgE synthesis. Clin Immunol Immunopatbol 1989; 50 S13-S23.

14. Vercelli D, Jabara HH, Lauener RP, Geha RS. IL-4 inhibits the synthesis of IFN- $\gamma$ and induces the synthesis of IgE in human mixed lymphocyte cultures. J Immunol 1990; 144: 570-573.

15. Paliard X, de Waal Malefijt R, Yssel $\mathrm{H}$ et al. Simultaneous production of IL-2, IL-4, and IFN- $\gamma$ by activated human $\mathrm{CD} 4^{+}$and $\mathrm{CD} 8^{+}{ }^{-} \mathrm{T}$ cell clones. J Immunol 1988; 141: 849-855.

16. Rousset F, Robert J, Andary M et al. Shifts in interleukin-4 and interferonproduction by $T$ cells of patients with elevated serum IgE levels and the modulatory effects of these lymphokines on spontaneous IgE synthesis. $J$ Allergy Clin Immunol 1991; 87: 58-69.

17. Butch AW, Pesando J, Levine AD, McKearn JP, Nahm MH. Cytokine production by $\mathrm{T}$ helper cell subpopulations during prolonged in vitro stimulation. Immunol Lett 1991; 27: 85-94.

18. Scott MG, Levine AD, Butch AW, Bowen MB, Macke KA, Nahm MH. Production, characterization and use of five monoclonal antibodies to human IL-4. Lymphokine Res 1990; 9: 81-93.

19. Kapp A, Gillitzer R, Kirchner H, Schöpf E. Production of interferon and lymphoproliferative responses in whole blood cultures derived from patient with atopic dermatitis. Arch Derm Res 1987; 279: S55-S58.

20. Wehrmann W, Reinhold U, Pawalec G, Wernet P, Kreysel H-W. In vitro generation of IFN-gamma in relationship to in vivo concentrations of IgE and $\mathrm{IgG}$ subclasses and $\mathrm{Fc}_{\varepsilon} \mathrm{R}_{\mathrm{I}} / \mathrm{CD} 23$-positive circulating lymphocytes in patients with severe atopic dermatitis. Acta Derm Venereol (Stockb) 1989 Suppl 144: 127-130.

21. Well S, Paetzold M, Choné K, Diel F. Interleukin-4 in mononuclear cell and histamine release in peripheral blood from an atopic patient in vitro. Agents Actions 1992; Special Issue C: C298-C301.

22. Le Gros G, Ben-Sasson SZ, Seder R, Finkelman FD, Paul WE. Generation of interleukin 4 (IL-4)-producing cells in vivo and in vitro: IL-2 and IL-4 are required for in vitro generation of IL-4-producing cells. J Exp Med 1990 172: $921-929$

23. Ben-Sasson SZ, Le Gros G, Conrad DH, Finkelman FD, Paul WE. IL-4 production by $\mathrm{T}$ cells from naive donors. IL-2 is required for IL-4 production. I Immunol 1990; 145: 1127-1136.

24. Vilcek J, Henriksen-Destefano D, Siegel D, Klion A, Robb RJ, Le J Reguation of IFN-gamma, induction in human peripheral blood cells by exogeneous and endogeneously produced interleukin 2 . J Immunol 1985; 135 1851-1855.

25. Hanifin JM, Rajka G. Diagnostic features of atopic dermatitis. Acta Derm Venereol (Stockh.) 1980; Suppl 92: 44-47.

26. Bøyum A. Isolation of mononuclear cells and granuloctes from human blood. Scand J Clin Lab Invest 1968; 21 : 77-89.

27. Matsumoto T, Miike T, Yamaguchi K, Murakami M, Kawabe T, Yodoi J. Serum levels of soluble IL-2 receptor, IL-4 and IgE-binding factors in childhood allergic diseases. Clin Exp Immunol 1991; 85: 288-292.

28. Romagnani S, Del Prete GF, Maggi E et al. Role of T cells and T-cell-derived cytokines in the regulation and deregulation of human immunoglobulin $\mathrm{E}$ synthesis. Advances in Allergology and Clinical Immunology, Proceedings of the XVth Congress of the EAACI, Paris, France, 1992; 9-14.

29. Parronchi P, Macchia D, Piccinni MP et al. Allergen and bacteria antigen-specific T-cell clones established from atopic donors show a different profile of cytokine production. Proc Natl Acad Sci USA 1991; 88: 4538-4542.

30. Del Prete G, Tiri A, Maggi E et al. Defective in vitro production of $\gamma$-interferon and tumor necrosis factor- $\alpha$ by circulating $T$ cells from patients with the hyperimmunoglobulin $\mathrm{E}$ syndrome. J Clin Invest 1989; 84: 1830-1835.

31. Reinhold U, Wehrmann W, Kukel S, Kreysel HW. Evidence that defective interferon-gamma production in atopic dermatitis patients is due to intrinsic abnormalities. Clin Exp Immunol 1990; 79: 374-380.

32. Reinhold U, Pawalec G, Wehrmann W, Herold M, Wernet P, Kreysel HW Immunoglobulin $\mathrm{E}$ and immunoglobulin $\mathrm{G}$ subclass distribution in vivo and relationship to in vitro generation of interferon-gamma in patients with severe atopic dermatitis. Int Arch Allergy Appl Immunol 1988; 87: 120-126.

33. Boguniewicz M, Jaffe HS, Izu A et al. Recombinant gamma interferon in the treatment of patients with atopic dermatitis and elevated IgE levels. $A m$ J Med 1990; 88: 365-370.

34. Kapp A, Kirnbauer R, Luger TA, Schöpf E. Altered production of immuno-modulating cytokines in patients with atopic dermatitis. Acta Derm Venereol (Stockh) 1989; Suppl 144: 97-99.

35. Seder RA, Le Gros G, Ben-Sasson SZ, Urban J Jr, Finkelman FD, Paul WE. Increased frequency of interleukin 4-producing $T$ cells as a result of 
polyclonal priming. Use of a single-cell assay to detect interleukin 4-producing cells. Eur J Immunol 1991; 21: 1241-1247.

36. van der Heijden FL, Wierenga EA, Bos JD, Kapsenberg ML. High frequency of IL-4-producing $\mathrm{CD} 4^{+}$allergen-specific $\mathrm{T}$ lymphocytes in atopic dermatitis lesional skin. J Invest Dermatol 1991; 97: 389-394.

37. Sager N, Feldmann A, Schilling G, Kreitsch P, Neumann C. House dust mite-specific $\mathrm{T}$ cells in the skin of subjects with atopic dermatitis: frequency and lymphokine profile in the allergen patch test. J Allergy Clin Immunol 1992; 89: 801-810.

38. Patarca R, Wei FY, Iregui MV, Cantor H. Differential induction of IFN- $\gamma$ gene expression after activation of $\mathrm{CD}^{+}{ }^{+} \mathrm{T}$ cells by conventional antigen and Mls superantigen. Proc Natl Acad Sci USA 1991; 88: 2736-2739.
ACKNOWLEDGMENTS. This work was supported in part by a grant from Hessisches Ministerium für Wissenschaft und Kultur. The authors are grateful to Dr Madeleine Ennis, Queen's University of Belfast, for her critical review of the manuscript and to the Allergie Verein in Europa AVE for co-operation in patient management.

Received 7 July 1993

accepted in revised form 2 September 1993 


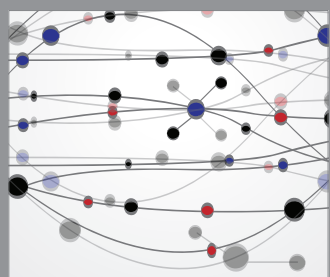

The Scientific World Journal
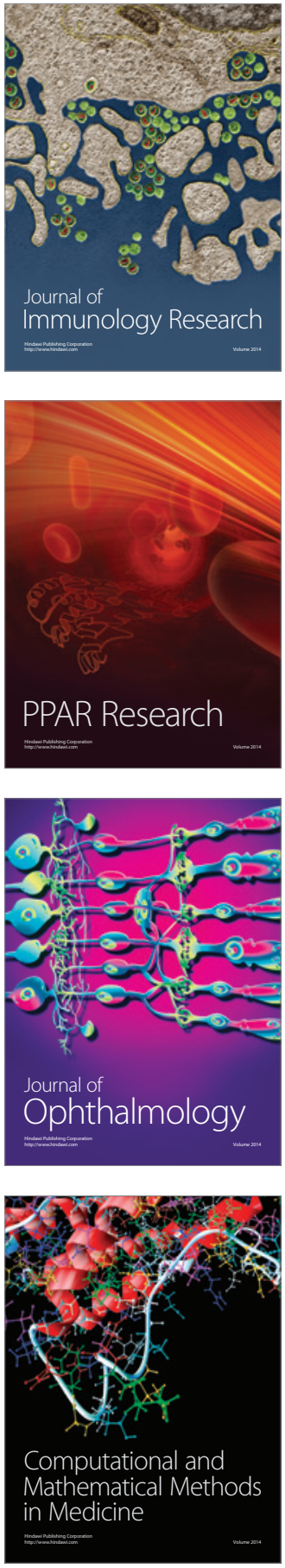

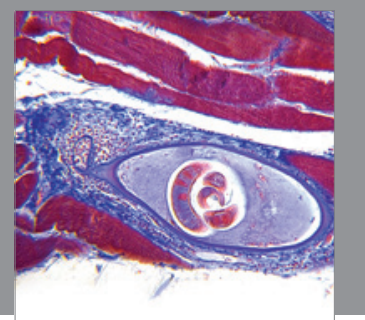

Gastroenterology

Research and Practice
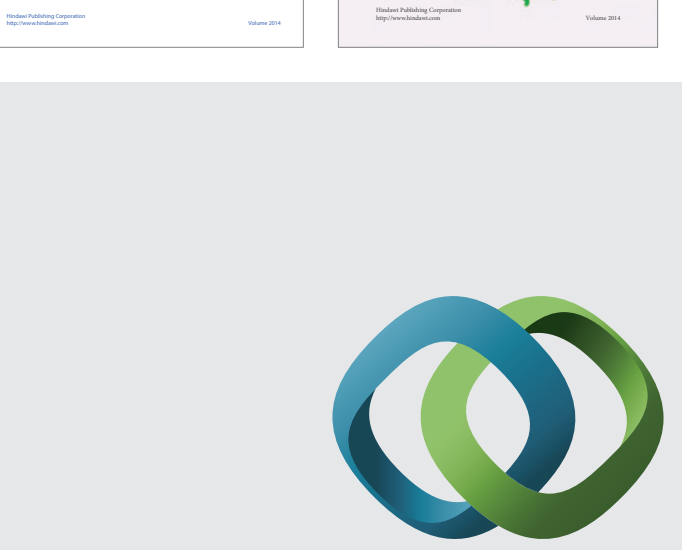

\section{Hindawi}

Submit your manuscripts at

http://www.hindawi.com
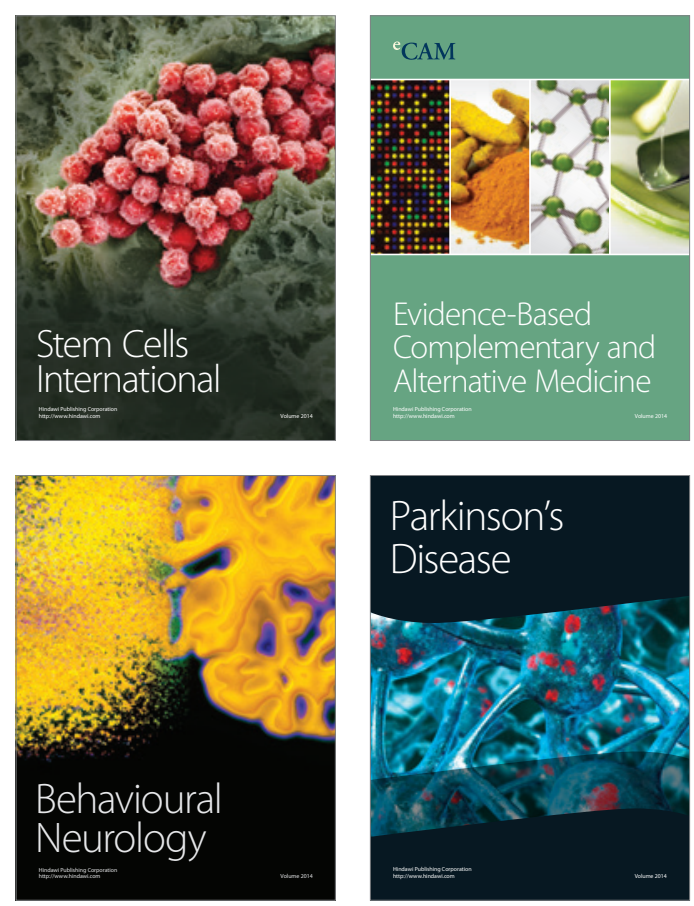

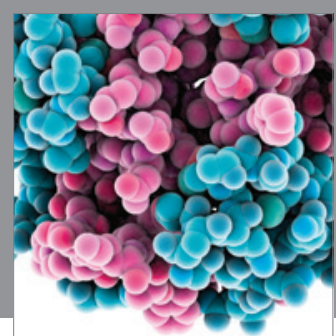

Journal of
Diabetes Research

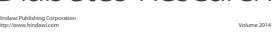

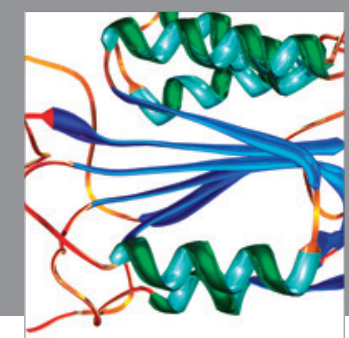

Disease Markers
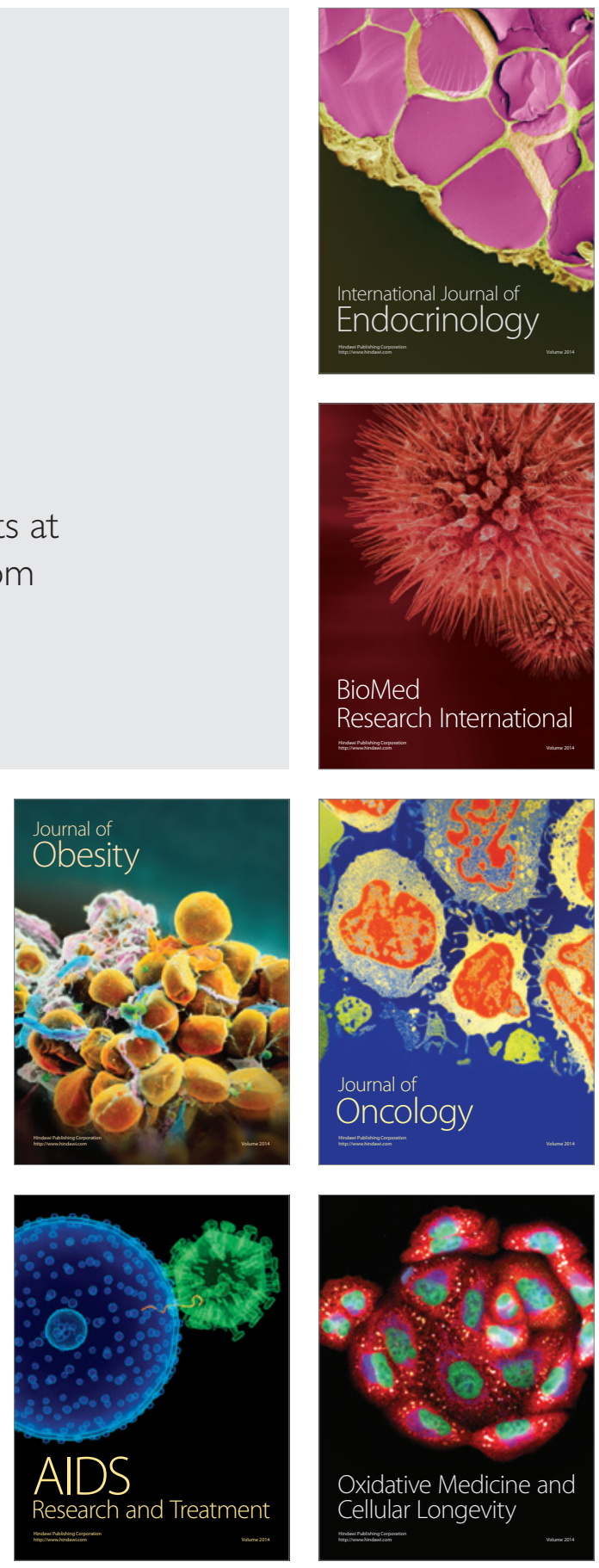